\title{
Exclamative Wh-Phrases as Positive Polarity Items*
}

\author{
Raquel González Rodríguez \\ Universidad de Castilla-La Mancha
}

\begin{abstract}
This paper studies the island effects induced by negation in exclamative sentences. In order to explain this phenomenon, I focus on the interaction between exclamative wh-phrases and negation, showing that negation can appear in exclamative sentences when the wh-phrase is not within the scope of negation; when the negative operator has wide scope, the sentence is ungrammatical. Assuming Szabolcsi and Zwarts's (1997) account of negative islands, I argue that the wh-phrase can have wide scope only when its domain is an unordered set, and not when it ranges over ordered sets. I argue that the inverse scope relation, where the wh-phrase is within the scope of negation, is always rejected, since wh-phrases are positive polarity items. I show that they are sensitive to downward-entailing contexts and propose that this is due to the fact that they widen a domain of quantification without strengthening the statement, in line with Kadmon and Landman's (1993) and Chierchia's (2004) analyses of negative polarity.
\end{abstract}

Key words: exclamative sentences, positive polarity, degree quantification, negative islands.

\section{Table of Contents}

\section{Introduction}

2. Two types of exclamative sentences

3. Scope effects in exclamative sentences
4. Negative islands and positive polarity 5. Conclusions

References

I would like to thank Cristina Sánchez López for her useful comments and guidance. Thanks also to Ricardo Etxepare, Myriam Uribe-Etxebarria for discussion and comments. Different parts of this research have been presented at the Swarthmore Workshop on Negation and Polarity, at the VII Congreso de Lingüistica General, at the $16^{\text {th }}$ Colloquium on Generative Grammar and at the Workshop on Clause Types and the Left Periphery. I want to thank all the audiences. Thanks also to two anonymous reviews for their comments. 


\section{Introduction}

As is well known, the studies on islands have shown that negation is a weak island, which blocks the extraction of some interrogative wh-phrases (cf. Ross 1984, Cinque 1990, Rizzi 1990, Frampton 1991, Kiss 1992, Kuno and Takami 1997, Szabolcsi and Zwarts 1997, Szabolcsi 2006, among many others). Thus, while some interrogative wh-phrases cannot be extracted across negation (cf. 1a), other wh-phrases can (cf. 1b):

(1) a. ¿Cómo no es Myriam de simpática?

'How nice is not Myriam?'

b. ¿Cuántas habitaciones no limpió Juan? 'How many rooms didn't John clean?'

Although the literature on the extraction of wh-phrases out of negative islands is very rich, little attention has been paid to the island effects induced by negation in exclamative sentences. As shown in (2), exclamative sentences also show restrictions with regard to the possibility of being negated (cf. Masullo 2003, Villalba 2004):

a. * ¡Cómo no es Myriam de simpática!

'How nice Myriam is not!'

b. ¡Cuántas habitaciones no limpió Juan! 'How many rooms John didn't clean!'

Note that the negative marker in (2b) contributes to the meaning of the sentence, modifying the truth value of the proposition, regardless of whether the expletive negation is also possible. I will deal with the presence of a standard negation in exclamative sentences, as opposed to focusing on expletive negation, which does not contribute to the meaning of the sentence. For an analysis of expletive negation in exclamative sentences, see Espinal (1997, 2000), Etxepare (1997) and Portner and Zanuttini (2000).

In this paper, I study in detail the conditions that determine the (un)grammaticality of negative exclamative sentences and propose a novel analysis of the restrictions on the presence of a non-expletive negation in exclamative sentences. The structure of this paper is as follows. In section 2, I propose a classification of exclamative sentences that will allow us to distinguish those that can be negated from those that cannot. Section 3 explores the interaction between exclamative wh-phrases and negation and shows which are the scope relations that can be established between these operators. Section 4 puts forward an analysis of the constraints on the interaction between those operators, which is based on the different properties of the set the wh-phrase ranges over and on the widening of a domain involved in exclamative wh-phrases. Section 6 concludes. 


\section{Two types of exclamative sentences}

Exclamative sentences are usually classified according to the category of the restrictor of the exclamative quantifier (cf. Gutiérrez-Rexach 2001, Villalba 2004, among others). Following this classification, the sentence in (3) is an adjectival exclamative; the construction in (4) is a nominal exclamative, and the sentence in (5) represents verbal exclamatives:

(3) ¡Qué guapo está tu hijo!

'How handsome your son is!'

(4) ¡Cuántos actores han trabajado en esa película!

'How many actors have worked in that film!'

(5) ¡Cómo la quiere!

'How much he loves her!'

While this is a very standard classification, it does not capture some important differences in the behavior of the three types of exclamatives. Thus, while some nominal exclamatives can be negated (6a), others cannot (6b) (cf. Villalba 2004). Verbal exclamatives give raise to the same contrast, as illustrated in (7):

(6) a. ¡Cuántos actores no han trabajado en esa película! 'How many actors have not worked in that film!'

b. *iQué coche no se ha comprado!

'What a car he has not bought!'

(7) a. ¡Cuánto no han leído esta semana!

'How much they have not read this week!'

b. * ¡Cómo no la quiere!

'How much he does not love her!'

Plann (1984), Torrego (1988) and Zanuttini and Portner (2003), among others, adopt an alternative classification of exclamatives that can capture these differences. According to this classification, exclamative sentences are divided into two groups, depending on the type of quantification denoted: quantitative and qualitative exclamatives. In quantitative exclamatives, like those in (8), the quantifier measures the amount of individuals or objects expressed by the restrictor. In qualitative exclamatives (9), on the other hand, the quantifier modifies items which are associated with a scale, pointing to a degree on the relevant scale:

(8) a. ¿Qué de criminales han sido arrestados! 'How many criminals have been arrested!'

b. ¡Cuánto han leído esta semana! 'How much they have read this week!' 
(9) a. ¡Qué criminales han sido arrestados!

'What criminals have been arrested!'

b. ¡Cómo la quiere!

'How much he loves her!'

c. ¿Qué inteligente es Isabel!

'How intelligent Isabel is!'

Quantitative and qualitative exclamatives can be subdivided according to the category of the restrictor of the wh-phrase:

Table 1

\begin{tabular}{lll}
\hline & Quantitative exclamatives & Qualitative exclamatives \\
\hline Adjectival exclamatives & & $\begin{array}{l}\text { (a) ¡Qué inteligente es Isabel! } \\
\text { 'How intelligent Isabel is!' }\end{array}$ \\
\hline Verbal exclamatives & (b) ¡Cuánto han leído esta semana! & (c) ¡Cómo la quiere! \\
& 'How much they have read this week!' & 'How much he loves her!' \\
\hline Nominal exclamatives & (d) iQué de criminales han sido arrestados! & (e) ¡Qué criminales han sido arrestados! \\
& 'How many criminals have been arrested!' & 'What criminals have been arrested!' \\
\hline
\end{tabular}

As is shown in table 1, adjectival exclamatives are always qualitative, since they measure the degree of the property in question, as in (a). In contrast, verbal and nominal exclamatives do not have unitary behavior with regard to the type of quantification denoted, and these can be either qualitatives or quantitatives. The quantitative verbal exclamative in (b) expresses the amount of readings achieved. As noted by Bosque and Masullo (1998), in these cases, the quantifier does not modify the predicate, it modifies an argument of its lexical structure. In contrast, in the qualitative exclamative (c), the meaning of the predicate is associated with a scale; thus, the sentence can be paraphrased as 'He loves her a lot'. Bosque and Masullo (1998: 20) propose that, in this type of quantification, 'the degree modifiers quantify over a component of the sub-lexical structure of the predicate, more specifically, the lowest predicate available in a lexical relational structure ${ }^{1}$. A similar situation is found in nominal exclamatives. The quantifier in the quantitative exclamative (d) expresses the amount of criminals; on the other hand, the qualitative nominal exclamative (e) denotes that the criminals that have been arrested have an unspecified property to an extreme (or high) degree. Following Castroviejo (2006), this type of exclamative sentences (e) contains an implicit Degree Phrase that is recovered from context. This Degree Phrase, which is headed by tan ('so') or más ('more'), can be introduced, as is shown in (10). This leads Castroviejo to propose that qué is not a degree operator in this type of exclamatives, but is only the element that contains the $[+w h]$ feature:

1. See Bosque and Masullo (1998) for a detailed analysis of this type of verbal quantification. 
(10) ¡Qué criminales $\{\tan /$ más $\}$ peligrosos han sido arrestados! 'What dangerous criminals have been arrested!'

Although the authors that adopt this classification do not pay attention to the possibility of negating exclamative sentences, I propose that the classification of exclamatives established by these authors allows us to distinguish those that can be negated from those that cannot. As the contrast between (11) and (12) shows, quantitative exclamatives can be negated (cf. 11), whereas qualitative ones cannot (cf. 12):

(11) a. ¿Qué de criminales no han sido arrestados!

'How many criminals have not been arrested!'

b. ¡Cuánto no han leído esta semana!

'How much they have not read this week!'

(12) a. * iQué criminales no han sido arrestados!

'What criminals have not been arrested!'

b. * ¡Cómo no la quiere!

'How much he does not love her!'

c. $*_{i}$ Qué inteligente no es Isabel!

'How intelligent Isabel is not!'

Any analysis of exclamatives needs to explain this contrast between quantitative and qualitative exclamatives.

\section{Scope effects in exclamative sentences ${ }^{2}$}

The proposal I put forward here is that the (im)possibility of negating exclamative sentences depends on the scope relations established between the wh-phrase and negation. In particular, I argue that negation can appear in exclamative sentences when it does not take scope over the wh-phrase; if the wh-phrase is within the scope of negation, the sentence is ungrammatical.

In the previous section, I mentioned that while quantitative exclamatives can be negated, qualitative exclamatives cannot. Crucially, one of the differences between quantifiers that range over individuals or objects and quantifiers that range over degrees is the scope relations these types of operators establish. Degree quantifiers always have narrow scope with respect to the rest of operators that appear in its

2. See González Rodríguez (to appear, a) for a more detailed description of the data presented in this section, which explores the scope relations established between exclamative wh-phrases and negation. On the one hand, González Rodríguez (to appear, a) shows that those data provide further support for the syntactic reconstruction approach to derive the scope relations established between two operators. On the other hand, the present work offers an analysis of the constrains on the interaction between exclamative wh-phrases and negation. 
sentence (cf. Kennedy 1997, Morón Pastor, 2004). ${ }^{3}$ So, the only possible reading of (13) is that given in (13a), in which very has narrow scope with respect to negation. The readings in (b) and (c) are not available. (13b), where negation takes wide scope, is not possible because it expresses that the subject has a property to a high degree, but, under this reading, that degree does not exist. ${ }^{4}$ The unavailability of the interpretation in (13c), in which the degree operator is not within the scope of negation, on the other hand, is due to the fact that it does not associate the individual with a degree on the scale: 5

(13) Irene no es muy alta.

'Irene is not very tall.'

a. "There is a degree $d$, such that Irene is tall to degree $d$, and $d$ is not a high degree on the scale of tallness."

[Neg > Very]

b. \#"There is not a degree $d$, such that $d$ is a high degree on the scale of tallness, and Irene is tall to degree $d . "$

$*[\mathrm{Neg}>$ Very $]$

c. \#"There is a degree $d$, such that $d$ is a high degree on the scale of tallness, and Irene is not tall to degree $d . "$

$*$ [Very $>\mathrm{Neg}]$

Consider now exclamative quantifiers that range over degrees, which we have illustrated in (14). Given what we have said above regarding the scope relations between negation and this type of quantifiers, the unavailability of the readings in (14b) and (14c) is expected. The former denies the existence of a maximal degree on the scale and, at the same time, affirms that the subject is tall to that degree. In the latter, the degree operator takes wide scope and the individual in question (Irene) is not associated with a degree on the scale (cf. Villalba, 2004). In contrast, the unavailability of the reading in (14a), where the wh-phrase has narrow scope with respect to negation, is unexpected. ${ }^{6}$ It is not obvious why an interpretation parallel

3. This leads Kennedy (1997) to propose that degree quantifiers are not operators. In contrast, Morón Pastor (2004) argues that degree modifiers are operators, in spite they do not establish scope relations.

4. Note that the two readings resulting from negation having wide scope over the quantifier are distinguished by the element that is the focus of negation. The interpretation in (13a) denies that the subject has the property in question to a high degree; the reading in (13b) denies the existence of that degree.

5. This intuition will be formalized in section 4.1.

6. Contrary to my judgments and Kennedy's (1997) view, Gutiérrez-Rexach (2001: 175) and Villalba (2004: 15) defend that exclamative degree operators always have wide scope. To illustrate this, Villalba (2004: 15) offers the example in (i), pointing out that the only possible interpretation is the one in (a):

(i) How expensive all the books are!

a. "Only one degree $d$ exists such that $d$ is the maximal degree on the scale of expensiveness and such that for every $y, y=$ book, $y$ is expensive to degree $d . "$

b. * "For every $y, y=$ book, only one degree $d$ exists such that $d$ is the maximal degree on the scale of expensiveness and such that $\boldsymbol{y}$ is expensive to degree $d . "$ 
to (13a), with negation taking scope over the degree phrase, is not available for (14a), in the same way it is possible for $(13 a):^{7}$

(14) * ¿Qué alta no es Irene! 'How tall Irene is not!'

a. \#"There is a degree $d$, such that Irene is tall to degree $d$, and $d$ is not the maximal degree on the scale of tallness."

$*[\mathrm{Neg}>$ Wh-Phrase $]$

b. \#"There is not a degree $d$, such that $d$ is the maximal degree on the scale of tallness, and Irene is tall to degree $d . "$

$*$ [Neg $>$ Wh-Phrase $]$

c. \#"There is a degree $d$, such that $d$ is the maximal degree on the scale of tallness, and Irene is not tall to degree $d$."

$*$ [Wh-Phrase $>\mathrm{Neg}]$

Quantifiers that range over individuals or objects, unlike degree quantifiers, which always take the narrowest scope possible, do establish different scope relations with other operators. So, the sentence in (15) is ambiguous between the interpretations in (a) and (c); in the former, the quantifier has narrow scope, in the latter, it takes scope over negation. Note that the scope relation in which negation has wide scope is only possible if it affects the appraisal of the quantity, as in (a), but not if the resulting interpretation implies the non existence of a certain number of mysteries, as shown in (b) (cf. Sánchez López 1999):

(15) Los detectives no despejaron muchas incógnitas.

'The detectives did not solve many mysteries.'

a. "There were mysteries that the detectives solved, and these were not many." [Neg > Many]

b. \#“There were not many mysteries that the detectives solved." $*[\mathrm{Neg}>\mathrm{Many}]$

c. "There were many mysteries that the detectives did not solve." [Many $>\mathrm{Neg}$ ]

But, crucially, quantitative exclamatives do not present the same behavior as quantifiers than ranges over individuals or objects when they co-appear with the negative particle. In that case, the exclamative wh-phrase must always be inter-

However, I consider that the reading of this sentence is the one in (b), but removing only, that is, the one in which each book has a different price. Note that, if we assume that degrees are intervals on a scale (cf. Kennedy 1997), that interpretation does not cancel the existence of a maximal degree on the scale. Any degree included in the highest interval is grammatically codified as an extreme degree. As a review notes, the reading in (b) is not possible if a distributive quantifier is introduced, as is shown by the ungrammaticality of *iQué alto es cada niño! ('How tall each boy is!'). The ungrammaticality of this sentence is due to the fact that there is not a variable which can be bounded by the distributive quantifier.

7. Villalba (2004) does not discuss this possibility. 
preted with wide scope. Negative quantitative exclamatives do not allow a wide scope reading of negation, as is shown in (16):

(16) ¡Cuántas incógnitas no despejaron los detectives!

'How many mysteries the detectives did not solve! ‘

a. \# "There were mysteries that the detectives solved, and these were not many.'

[Neg $>$ Wh-Phrase]

b. \#"There were not many mysteries that the detectives solved." $*$ [Neg $>$ Wh-Phrase $]$

c. "There were many mysteries that the detectives did not solve." [Wh-Phrase $>$ Neg]

The contrast in (15a) and (16a) shows that only the interpretation resulting from negation having narrow scope is available in negative exclamatives. But, again, there seems to be no explanation for the unavailability of the interpretation where the wh-phrase is within the scope of negation, specially considering that it is possible for their non-exclamative quantifier counterparts.

The results so far are summarized in table 2:

Table 2

\begin{tabular}{lll}
\hline & Qualitative Exclamatives & Quantitative Exclamatives \\
\hline *Neg $>$ Wh-Phrase & $\begin{array}{l}\text { Expected, though unavailable (14a): } \\
\text { different to non-exclamative quantifiers }\end{array}$ & $\begin{array}{l}\text { Expected, though unavailable (16a): } \\
\text { different to non-exclamative quantifiers }\end{array}$ \\
\cline { 2 - 3 } & $\begin{array}{l}\text { Unexpected and unavailable (14b): } \\
\text { similar to non-exclamative quantifiers }\end{array}$ & $\begin{array}{l}\text { Unexpected and unavailable (16b): } \\
\text { similar to non-exclamative quantifiers }\end{array}$ \\
\hline Wh-Phrase $>$ Neg & $\begin{array}{l}\text { Unexpected and unavailable (14c): } \\
\text { similar to non-exclamative quantifiers }\end{array}$ & $\begin{array}{l}\text { Expected and available (16c): } \\
\text { similar to non-exclamative quantifiers }\end{array}$ \\
\hline
\end{tabular}

The (im)possibility of negating exclamative sentences depends on the interaction between the wh-phrase and negation. Negation is allowed in exclamative sentences when it has narrow scope with respect to the wh-phrase. This scope relation arises when the wh-phrase ranges over individuals or objects, but not when it ranges over degrees, since these always have narrow scope. Given this, we can account for the asymmetry between quantitative and qualitative exclamatives with regard to the possibility of being negated: the former admit the negative particle, while the latter do not.

\section{Negative islands and positive polarity}

Once I have explored the interaction between exclamative wh-phrases and negation, I will now offer an analysis of the scope relations than can (or cannot) be 
established between these operators. First, I will focus on the scope relation in which the wh-phrase has scope over negation. Second, I will propose that the impossibility of negation having wide scope over the wh-phrase follows from the semantic properties of the latter.

\subsection{A semantic approach to negative islands}

As is well known, the negative operator blocks the extraction of some interrogative wh-phrases, and, therefore, is a weak island:

(17) a. * ¿Cómo de clara no fue su exposición?

'How clear was not his presentation?'

b. ¿Cuántos regalos no compró?

'How many gifts didn't he buy?'

Semantic approaches treat the contrast in (17) as a scope phenomenon (cf. de Swart 1992, Kiss 1992, Szabolcsi and Zwarts 1997). Szabolcsi and Zwarts's (1997) analysis of weak islands, such as negation, is based on the assumptions in (18)(20):

(18) The weak island effect comes about when the wh-phrase should take wide scope over some operator but it is unable to.

(19) Scope and operations: Each scope element SE is associated with certain operations (e.g., not with complements). For a wh-phrase to take wide scope over some SE means that the operations associated with SE need to be performed in wh's denotation domain. If the wh-phrase denotes in a domain for which the requisite operation is not defined, it cannot scope over SE.

(20) Individuality and wide scope taking: When a wh-phrase ranges over discrete individuals, these can be collected into unordered sets. All Boolean operations can be performed on such sets. When a wh-phrase does not range over discrete individuals, only a smaller set of operations (possibly none) are available in its denotation domain, hence answers cannot be defined in the general case.

(Szabolcsi and Zwarts 1997: 229, 232 and 233)

According to these assumptions, negative islands arise when the operation associated with negation cannot perform in wh's denotation domain. This happens when the wh-phrase denotes in a partially ordered domain, but not when it denotes in unordered sets. Consider, for instance, the contrast between (21) and (22):

(21) *How fast can't John run? 
(22) How many women don't you know here?

a. "Which of the women don't you know?"

b. \#"For what amount of women, don't you know them?"

In (21), the wh-phrase, how fast, ranges over an ordered set, degrees on a scale of fastness, so that the negative operator cannot perform in this domain. In (22), negation does not block the extraction of the wh-phrase if this ranges over a set of individuals, that is, if the interrogative sentence is interpreted as in (22a). This paraphrase arises, for instance, when, in a party, the host asks a guest about the women that he does not know. The possibility of extracting the wh-phrase under this interpretation is due to the fact that sets of individuals form Boolean algebras, and negation can perform on these structures. In contrast, if the wh-phrase ranges over amounts, as in (22b), where the speaker asks about the amount of women that he does not know, the negative operator blocks the relevant interpretation. Amounts cannot be closed under complements, since they do not form a Boolean algebra.

The asymmetry between wh-phrases with regard to the possibility of being extracted across weak islands cannot be explained in terms of referentiality or D(iscourse)-linked (cf. Cinque 1990, Rizzi 1990), but in terms of quantification over individuals or objects (cf. Szabolcsi and Zwarts 1997). The D-linked is not a condition that is either necessary or enough for wh-phrases to be extracted across a weak island. This notion is relevant only because it forces the individualization of the set that the wh-phrase ranges over, and, as a consequence, more operations can be performed on such sets. Szabolcsi and Zwarts's argumentation is based on the ambiguity of wh-phrases headed by cîte ('how many') in Romanian. According to Dobrovie-Sorin (1992), these wh-phrases have three different interpretations: amount (cf. 23a), non-D-linked individual (cf. 23b) and D-linked individual (cf. 24). As is illustrated in (24), D-linked human direct objects in Romanian are clitic-doubled. The grammaticality of (23b), where a non-D-linked wh-phrase is extracted across a factive island, shows that the Dlinked is not crucial in order to understand the possibility of extracting wh-phrases. The D-linked wh-phrase (cf. 24) can be extracted because it forces the individualization of the wh's domain. The reading paraphrased in $(23 \mathrm{a})$, where the wh-phrase ranges over amounts, is not possible because the domain of the whphrase is an ordered set.

(23) Cîte femei regreti câ ai iubit?

How-many women regret-you that have loved

a. *"For what amount of women, you regret having loved that amount of women?"

(Answer: Three.)

b. "How many women are there such that you regret having loved them?" (Answer: There are three such women.) 
(24) Pe cite femei regreti câ le ai iubit? prep how-many women regret-you that cl have loved 'How many [=which] of the women do you regret having loved?' (Three of them, namely, A, B, and C.) $\left(\right.$ Dobrovie-Sorin 1992) ${ }^{8}$

In a similar way, wh-phrases headed by how many could be extracted across negation only if the relevant reading is the one in which it ranges over individuals or objects. Thus, (25) is grammatical when the D-linked induces the individualization of wh's domain; for example, if there is a list of scores and receivers' names on the blackboard:

(25) How many scores did no one receive? (Answer: 22 and 27) 'Which of the figures on the blackboard has no name next to it?' (Szabolcsi and Zwarts 1997: 237)

The individualization of the domain is more difficult when the restrictor of the wh-phrase is an uncountable noun. So, while it is easy to imagine a situation in which cuántos coches ('how many cars') refers to a specific set of individuals, it is difficult to imagine a similar situation if the wh-phrase is, for instance, cuánto dinero ('how much money'). According Szabolcsi and Zwarts's proposal, this explains the contrast between ¿Cuántos coches no vendió? ('How many cars didn't he buy?') and * ¿Cuánto dinero no gastó? ('How much money didn't he spend?'). But, although the individualization of the uncountable noun is difficult, it can be obtained, as is shown by the possibility of asking ¿Cuánta cerveza no se bebió? ('How much beer didn't he drink?') if the answer is medio vaso ('half of a glass'), but not when the answer is mucha ('much').

Considering the parallelism between interrogative and exclamative wh-phrases when they are extracted across a negative island (cf. section 1), I propose that Szabolcsi and Zwarts's (1997) analysis can be extended to exclamative sentences, such as the ones in (26) and (27):

(26) *iQué alto no es Pedro!

'How tall Peter is not!'

a. \#"There is a degree $d$, such that $d$ is the maximal degree on the scale of tallness, and Peter is not tall to degree $d$." *[Wh-Phrase $>$ Neg]

b. \#"There is a degree $d$, such that Peter is tall to degree $d$, and $d$ is not the maximal degree on the scale of tallness."

$*[\mathrm{Neg}>$ Wh-Phrase $]$ 
(27) ¡Cuántos estudiantes no aprobaron el examen!

'How many students didn't pass the exam!'

a. "There are many students that didn't pass the exam." [Wh-Phrase $>$ Neg]

b. \#"There are students that passed the exam, and they are not many." $*[\mathrm{Neg}>$ Wh-Phrase $]$

Once we extend Szabolcsi and Zwarts's proposal to exclamative sentences, we can explain why the interpretation resulting from the wh-phrase having wide scope is only available in (27). The possibility of having the interpretation in (27a) is due to the fact that the wh-phrase can range over an unordered set of individuals, and, the operation associated with negation is available in this denotation domain, causing the derivation to converge under this reading (cf. 19-20). ${ }^{9}$ In contrast, the whphrase in (26a) ranges over an ordered set, the one formed by degrees on the scale of tallness, and negation cannot perform on this type of set (cf. 19-20). ${ }^{10}$ In this sense, a review judges that qualitative exclamatives can be negated if a salient context makes available the set of individuals modified by means of the negative predicate:

(28) a. Ayer repasé la lista de los diez criminales más buscados y vaya/menudos elementos que aún no habían sido detenidos.

'I reviewed yesterday the list of the ten more wanted criminals and what guys have not been arrested yet.'

b. Contempla esta urbanización de lujo y podrás ver lo ricos que no llegaremos a ser nunca.

'Look at this luxury urbanization and you could see how rich we will never become.'

c. ¿Has visto qué chalets? ¡Menudas casas que no nos podremos comprar nunca!

'Have you seen these houses? What houses we could never buy!'

Although the judgments seem subtle, since, according to my informants, the sentences in (28) are not completely fine, I would like to suggest that the contrast between these constructions (cf. 28) and the one in (26) could be explained if we take into consideration the notion of 'individualization'. As I pointed out, the D-

9. Note that, under this interpretation, cuántos ('how many') ranges over individuals. I put aside the reading resulting from the quantifier ranging over quantities, since it is unavailable, as I pointed out above. I will disregard this interpretation in the remainder of this paper.

10. The same explanation should be extended to qualitative exclamatives such as *iQué criminal no ha sido arrestado! ('What a criminal has not been arrested!') if we assume that they contain an implicit Degree Phrase headed by tan ('so') or más ('more'), which range over degrees (cf. Castroviejo 2006). The degree operator contained in the wh-phrase could not have wide scope over negation because its domain is an unordered set. 
linked forces the individualization of the set of elements which forms the wh's denotation domain (cf. Szabolcsi and Zwarts 1997). Thus, the specificity of the set in (28) induces its individualization, and, following Szabolcsi and Zwarts, if the wh-phrase ranges over an unordered set, it can take scope over negation.

Thus, the proposal developed by Szabolcsi and Zwarts can account for the (im)possibility of having the scope relation in which the exclamative wh-phrase takes wide scope. However, their hypothesis does not explain why the other scope relation, that is, the one in which negation takes wide scope cannot be established either in quantitative exclamatives or in qualitative ones. Remember that the readings in (26b) and (27b) are expected, though unavailable. ${ }^{11}$ Thus, it is clear that something else should be said to account for the unavailability of (26b) and (27b). In the following section, I offer an explanation of why this is so. This explanation is based on the proposal that exclamative wh-phrases are positive polarity items.

\subsection{Exclamative wh-phrases as positive polarity items}

In this section, I will explain why the scope relation in which exclamative whphrases are within the scope of negation is not possible, arguing that this restriction is an instance of the more general phenomenon of polarity sensitivity. First, I will show that exclamative quantifiers are positive polarity items. Second, I will put forward an analysis that explains the sensitivity of these items to downwardentailing environments

\subsubsection{The distribution of positive polarity items: exclamative wh-phrases}

Since Ladusaw's (1980) work, the negative contexts, which license negative polarity items (NPIs), have been characterized as downward-entailing environments (cf. Hoeksema 1986, van der Wouden 1997 and Zwarts 1998, among others). ${ }^{12}$ According to this theory of polarity, there are three types of polarity triggers: downward-entailing functions, anti-additive functions and anti-morphic functions. ${ }^{13}$ Van der Wouden (1997) shows that these contexts are also relevant for positive polarity items (PPIs), which are incompatible with certain environments. Depending on whether PPIs cannot co-occur with downward-entailing, anti-additive or anti-morphic operators, van der Wouden distinguishes between strong, medium and weak PPIs, respectively.

11. Under the syntactic approach to negative islands (cf. Cinque 1990, Rizzi 1990, among others), the extraction of the wh-phrase in (26) is blocked because its variable is not governed. In (26), the scope relation in (27b) would be predicted to be possible, since the wh-phrase is D-linked. However, this prediction is not borne out. This fact gives evidence in favor of negative islands as a scope phenomenon.

12. I will assume this theory of polarity, in which NPIs are licensed only when they are located in the scope of downward-entailing functions, although I am aware that this framework faces empirical problems, which seem to disappear in the case of Positive Polarity (see footnote 17).

13. A function is downward-entailing if: (a) $\mathrm{a} \subseteq \mathrm{b}$ and (b) $\mathrm{f}(\mathrm{b}) \rightarrow \mathrm{f}(\mathrm{a})$. A function is anti-additive if $f(X \cup Y)=f(X) \cap f(Y)$. A function is anti-morphic if $(a) f(X \cup Y)=f(X) \cap f(Y)$ and $(b) f(X \cap Y)$ $=f(X) \cup f(Y)$. 
My proposal is that exclamative wh-phrases are PPIs. ${ }^{14}$ I showed that exclamative wh-phrases cannot be within the scope of negation, and, therefore, they are at least sensitive to anti-morphic contexts. The data in (29) illustrate once again that paradigm in qualitative (cf. 29a) and quantitative exclamatives (cf. 29b). The interpretation paraphrased below the examples in (29), where the quantifier has narrow scope, is expected, although unavailable, in both types of exclamatives: ${ }^{15}$

(29) a. *iQué bella no es esta melodía!

'How beautiful this melody is not!'

\#"There is a degree $d$, such that this melody is beautiful to degree $d$, and $d$ is not the maximal degree on the scale of beautifulness."

*[Neg $>$ Wh-Phrase $]$

b. ¡Cuántos criterios no tuvo en cuenta!

'How many criteria he did not pay attention to!'

\#"There are criteria that he paid attention to, and these were not many." $*$ [Neg $>$ Wh-Phrase $]$

The preposition $\sin$ ('without') is an anti-additive function and allows us to check whether exclamative wh-phrases are sensitive to anti-additive contexts. As the contrast between (30a) and (30b) shows, con ('with') can be followed by exclamative wh-phrases (cf. 30a), while the preposition $\sin$ ('without') cannot (cf. 30b):

(30) a. ¡Con qué labia les sedujo!

'With such a loquacity he seduced them!'

b. *iSin qué labia les sedujo!

'Without such a loquacity he seduced them!'

In contrast with (30), the sentences in (31) and (32) are both grammatical because the exclamative quantifier in (32) can outscope negation ('There are many tools with which he didn't fix the car'). However, the impossibility of having the reading in which the exclamative quantifier has narrow scope with respect to $\sin$ (\#"There are tools with which he fixed the car and they are not many"), shows that quantifiers which range over individuals or objects, like degree quantifiers, cannot be within the scope of that preposition:

14. It should be noted that it is not contradictory to simultaneously assert that exclamative wh-phrases are operators which bind a variable and that they are PPIs. The reason is that I am assuming a theory of positive polarity in which PPIs are not variables which must be bound by a positive operator, but they are anti-licensed items (cf. Giannakidou 1998, González Rodríguez to appear, b). Thus, PPIs are characterized by being incompatible with negative contexts as a consequence of the lexical semantics of PPIs.

15. Remember that there is another reading resulting from negation having wide scope (\#"There is not a degree $d$, such that $d$ is the maximal degree on the scale of beautifulness, and this melody is beautiful to degree d' and \#'There are not many criteria that he paid attention to"). But, as I pointed out in section 3 , the reasons that exclude these readings are different. 
(31) ¡Con cuántas herramientas arregló el coche! 'With how many tools he fixed the car!'

(32) ¡Sin cuántas herramientas arregló el coche! 'Without how many tools he fixed the car!'

The data in (30)-(32) show that exclamative wh-phrases are sensitive to antiadditive environments; they cannot appear within the scope of these functions. The behavior of exclamative quantifiers in downward-entailing environments further confirms that they are PPIs, since they are incompatible with those contexts. For example, raramente ('rarely') is a downward-entailing operator, and exclamative wh-phrases cannot have narrow scope with respect to it. This explains the ungrammaticality of (33a), where the degree quantifier can only have narrow scope (cf. section 3), as well as the impossibility of having the interpretation resulting from negation having wide scope in (33b) (\#“There are quiz shows that John watches, and they are rarely many"):

(33) a. *iQué motivados están raramente sus empleados! ${ }^{16}$ 'How motivated his employees are rarely!'

b. ¡Cuántos concursos ve raramente Juan! 'How many quiz shows John rarely watches!'

Note that, as we see in (34), the situation changes when the sentence contains a temporal adverb which is not downward-entailing, such as frecuentemente ('frequently'). In this case, qualitative exclamatives are grammatical (cf. 34a) and quantitative ones have the reading resulting from the quantifier having narrow scope (cf. 34b) ('There are quiz shows that John watches, and they are frequently many'):

(34) a. ¿Qué motivados están continuamente sus empleados!

'How motivated his employees are frequently!'

b. ¡Cuántos programas ve frecuentemente Juan! 'How many quiz shows John frequently watches!'

The data above show that exclamative quantifiers are PPIs. Since they are sensitive to downward-entailing contexts, they are strong PPIs. ${ }^{17}$ Their impossibility

16. This sentence is ungrammatical regardless of whether the negative adverb precedes the verb, as in *iQué motivados raramente están sus empleados!, although there are other reasons to rule out this construction, since the focalized element precludes the presence of other constituent that precedes the verb. In order to check whether there is the (in)compatibility between wh-phrases and downward-entailing contexts, I will place the negative adverb in the postverbal position.

17. Interestingly, exclamative wh-phrases are ungrammatical even when they are in the scope of downward-entailing operators which do not license NPIs, such as como mucho $N$ ('at most N'): *iQué honestos son como mucho tres politicos! ('How honest at most three politicians are!'). That como mucho $N$ ('at most N') does not license NPIs is shown by the ungrammaticality of *Como mucho 
of being within the scope of negation is only an instance of their sensitivity, so that negation is an anti-morphic (and, in consequence, a downward-entailing) operator.

\subsubsection{The sensitivity of exclamative wh-phrases and the semantics of widening a domain of quantification}

Exclamative wh-phrases cannot be within the scope of downward-entailing contexts. This constraint shows that they are PPIs, but it does not explain why they are sensitive to those contexts. In this section, I will address this issue, deriving the sensitivity of exclamative quantifiers from their semantic properties, in line with Israel (1996), Giannakidou (1998), Lahiri (1998), Tovena (1998), Chierchia (2004, 2006), among others. As noted by Zanuttini and Portner (2003), exclamative quantifiers are operators that bind a variable, inducing a scalar implicature. These elements express that the scale in question has been extended far beyond the speaker's expectations. For example, (35) indicates that the price of the ticket has exceeded the speaker's expectations:

¡Qué caro ha sido el billete!

'How expensive the ticket has been!'

Based on Kadmon and Landman (1993), Zanuttini and Portner (2003) name this property 'widening' because the bound variable is out of the domain of quantification expected by the speaker, deriving in that the domain is widened. In (35), the expected domain with regard to prices of a plane ticket would be that in (36a), for instance, and the exclamative operator widens the domain to (36b):

(36) a. $D_{1}:\{400$ euros, 500 euros, 600 euros $\}$

b. $\mathrm{D}_{2}$ : $\{400$ euros, 500 euros, 600 euros, 700 euros, 800 euros, 900 euros $\}$

Although Zanuttini and Portner (2003: 50, n. 15) suggest that there is a certain relation between the widening that conveys exclamative sentences and the one involved in the meaning of any (cf. Kadmon and Landman 1993), they do not explore the nature of that relation. I would like to propose that this relation exists and is essential in order to understand the sensitivity of exclamative wh-phrases, in a manner parallel to the explanation of the NPI any proposed by Kadmon and Landman (1993) and Chierchia (2004). As Kadmon and Landman (1993) point out, any widens a domain of quantification because, in a NP of the form any NP, any extends the interpretation of the common noun. Thus, in (37), any widens, for example, the domain of quantification in $\mathrm{D}_{1}$ to the one illustrated in $\mathrm{D}_{2}$ :

tres políticos dijeron nada ('At most three politicians said anything'). Although this fact constitutes an empirical problem for DE-based theories of negative polarity, the same problem does not arise in the case of positive polarity. 
(37) a. I don't have any potatoes.

b. $\mathrm{D}_{1:}$ \{ cooking potatoes $\}$

c. $\mathrm{D}_{2:}$ \{cooking potatoes, non-cooking potatoes (adapted from Kadmon and Landman 1993: 359)

According to Chierchia (2004), the domain-widening function must be universally closed. This closure is subject to a strengthening condition, that is, the result must be a stronger statement, giving rise to a gain of information. ${ }^{18}$. In the case of any, the closure 'must lead to something stronger than the corresponding meaning with a plain indefinite' (cf. Chierchia, 2004: 76).

The combination between the widening effect and the strengthening principle allows Kadmon and Landman (1993) and Chierchia (2004) to derive the sensitivity of any, that is, this item can only occur in downward-entailing contexts. ${ }^{19}$ When it appears in these environments, the strengthening condition is satisfied, the reason being that downward-entailing operators create entailments from sets to subsets. As is shown in (38), the statement in which the domain has been extended (cf. 38a) entails the one in which the domain has not been widened (cf. 38b):

(38) a. wide: We don't have potatoes, cooking or others.

b. $\Rightarrow$ narrow: We don't have cooking potatoes.

(Kadmon and Landman 1993: 370)

In contrast, the strengthening condition is not satisfied when any occurs in affirmative contexts, since the direction of the entailments is the opposite one. As is shown in (39), the result of the widening in affirmative environments does not lead to something stronger, violating the strengthening principle:

(39) a. wide: We have potatoes of SOME kind (cooking or other).

b. $=/ \Rightarrow$ narrow: We have cooking potatoes.

(Kadmon and Landman 1993: 370)

The use of any in these contexts leads to a loss of information, causing the ungrammaticality of the sentence:

(40) *I have any potatoes.

Assuming this approach to negative polarity, my proposal is that exclamative whphrases are PPIs because they induce a domain-extension which creates a stronger statement, not in downward-entailing contexts, but in affirmative environments. Thus, when exclamative quantifiers occur within the scope of a downward-entail- 
ing operator, the strengthening condition is not satisfied, causing the ungrammaticality of the sentence. As I pointed out, exclamative quantifiers extend the interval of the scale which is relevant in order to localize the subject of predication. ${ }^{20}$ The widening involved in exclamative quantifiers is illustrated in (41), where $D_{1}$ constitutes the initial domain and $\mathrm{D}_{2}$ exemplifies the widened domain. The same situation is found in quantitative exclamatives (cf. 42):

(41) a. ¡Qué alto es Juan!

'How tall John is!'
b. $\mathrm{D}_{1}:\{1.70 \mathrm{~m}$ (eters), $1.80 \mathrm{~m}\}$
(narrow domain)
c. $\mathrm{D}_{2}:\{1.70 \mathrm{~m}, 1.80 \mathrm{~m}, 1.90 \mathrm{~m}, 2 \mathrm{~m}, 2.10 \mathrm{~m}\}$ (widened domain)

(42) a. ¡Cuántos artículos ha publicado! 'How many papers he has published!'
b. $D_{1}:\{2,3,4\}$
(narrow domain)
c. $D_{2}:\{2,3,4,5,6,7,8\}$
(widened domain)

Exclamative quantifiers widen the domain of quantification towards the top of the scale, expressing that the degree to which the subject is localized is higher than the one expected by the speaker: (43) a. ¿Qué alto es Juan!
'How tall John is!'
b. $\mathrm{D}_{1}:\{1.70 \mathrm{~m}, 1.80 \mathrm{~m}\}$
(narrow domain)
c. $\mathrm{D}_{2}:\{1.70 \mathrm{~m}, 1.80 \mathrm{~m}, 1.90 \mathrm{~m}, 2 \mathrm{~m}, 2.10 \mathrm{~m}\} \quad$ (widened domain)

As a consequence of the direction in which the quantifier extends the domain, the resulting statement is stronger than it would be without the widening in affirmative contexts. In other words, the widening associated with exclamative quantifiers leads to a gain of information. Given a degree $x$ and a degree $y$, such that $x$ is high-

20. The fact that any and exclamative operators widen a domain of quantification implies that both elements are constrained by a contextual domain restriction. This is standardly assumed for quantification over individuals or events (cf. von Fintel 1994), but not for quantification over degrees. However, if the contextual restriction of a domain is a general property of quantification, it seems reasonable to extend it to the field of degree quantification (cf. Morzycki 2004: 19). In the same way as in (ia) the domain of quantification is contextually restricted to a set of individuals, the degree operator in (ib) quantifies over degrees which are placed in a particular interval on the scale. As Morzycki (2004) points out, this explains that there is something surprising about both constructions, (ia) and (ib):

(i) a. Someone showed up during office hours. It was \{Queen Victoria/Gadzork the Martian\}.

b. Clyde is tall. He's \{about 6 or 7 kilometers/the same height as his apartment building\}. (Morzycki 2004: 20) 
er on the scale than $\boldsymbol{y}$, the sentence John is $x$ entails John is $y$. In other words, the direction of entailments is the one indicated by the arrow in (44):

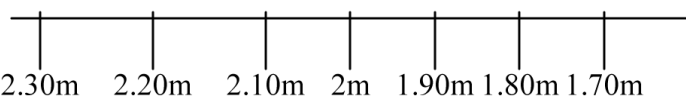

So, as is shown in (45), if it is the case that an individual is 2 meters tall, it must also be the case that he is 1.90 meters tall, 1.80 meters tall, etc.. ${ }^{21}$

\section{(45) John is 2 meters tall $==>$ John is 1.80 meters tall}

This shows that the widening of the domain of quantification induced by exclamative quantifiers satisfies the strengthening constraint in affirmative contexts. ${ }^{22}$ In contrast, this principle is not satisfied in downward-entailment environments, in which the widening induced by exclamative quantifiers leads to a loss of information. Let us consider, for example, the case of negation. The result of the widening induced by the exclamative wh-phrase in the negative sentence illustrated in (46a) is the same as the one in the affirmative construction. That is, the interval of the scale which is relevant is extended towards the top of the scale (cf. 46b-c):

(46) a. *iQué alto no es Juan!

' How tall John is not!'

b. $\mathrm{D}_{1}:\{1.70 \mathrm{~m}, 1.80 \mathrm{~m}\}$

(narrow domain)

c. $\mathrm{D}_{2}:\{1.70 \mathrm{~m}, 1.80 \mathrm{~m}, 1.90 \mathrm{~m}, 2 \mathrm{~m}, 2.10 \mathrm{~m}\}$ (widened domain)

Crucially, the result of the domain expansion in (46) does not lead to a stronger statement, but to a weaker one, the opposite of what occurs in affirmative sentences (cf. 45). The reason is that (47a) does not imply (47b). The entailment of (47a) is that John is not 2.5 meters tall, 3 meters tall, and so on (cf. $47 \mathrm{c}):^{23}$

21. Note that this reading arises when the sentence is interpreted as in (i), but not when it is paraphrased as in (ib):

(i) a. John reaches two meters tall.

b. John is exactly two meters tall.

Since exclamative sentences have the former reading, the second interpretation must be excluded.

22. I do not address here whether this requirement is a lexical property of exclamative quantifiers (cf. Kadmon and Landman 1993) or a condition that the universal closure associated with the domain expansion must satisfy (cf. Chierchia 2004).

23. Remember that I am not dealing with the interpretation of (47a) which can be paraphrased as 'John is not exactly two meters tall' (cf. footnote 21). According to this reading, (47a) does not entail (47b). In contrast, this relation holds under the other reading ('John does not reach two meters'), as shown by the anomaly of John does not reach two meters, although he reaches 2.25 meters. 
(47) a. John is not two meters tall.
b. $=/ \Rightarrow$ John is not 1.80 meters tall.
c. $\Rightarrow$ John is not 2.10 meters tall.

The negative operator reverses entailments, so that the direction of the entailments is the one indicated by the arrow in (48):

(48) Downward-entailment contexts

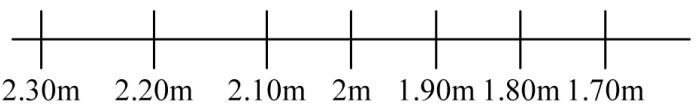

Since the negative operator, like the rest of downward-entailing functions, reverses scalar entailments, the widening associated with exclamative wh-phrases does not satisfy the strengthening condition. The violation of this principle causes the ungrammaticality of the sentence in (46), as well as the ungrammaticality of the exclamatives in which the wh-phrase must be interpreted within the scope of a downward-entailing function.

Before closing this section, I would like to discuss the possibility of extending my proposal to the ungrammaticality of the following negative exclamative sentences:

(49) a. *iQué poco inteligente no es María!

'How little intelligent Mary is not!'

b. *iQué poco seguro no es ese mecanismo!

'How little sure this mechanism is not!'

Zanuttini and Portner's description of exclamative sentences seems not to apply to these constructions. The degree on the scale in which the subject of predication is placed in these exclamatives is not higher than the degree expected by the speaker, but rather is lower than it; for example, in (49a), the speaker expresses that the degree of intelligence of María is lower than the degree expected by him. Therefore, in these cases, it is not possible to defend that exclamative quantifiers widen a domain of quantification, and, as a consequence, that they are sensitive to negation because, when appearing in that context, the extension domain induced by them does not lead to a stronger statement.

However, I assume that the exclamatives illustrated in (49) are not a counterexample to our hypothesis. If we assume the ontology of degrees proposed by Kennedy $(1997,2001 \mathrm{a}, \mathrm{b})$, it is possible to argue that the exclamatives in (49) do not differ from the ones studied before (;Qué inteligente es María! 'How intelligent Mary is!'). This author proposes that gradable adjectives denote functions from objects to intervals (or extents) on a scale and distinguishes between positive extensions and negative extensions: 
(50) A positive extent on a scale is a proper extent on a scale that ranges from the lower end of the scale to some positive point.

(51) A negative extent on a scale is a proper extent on a scale that ranges from some positive point to the upper end of the scale.

(Kennedy 1997: 200)

Positive extents and negative extents are defined in (52a) and (52b), respectively, where $a$ represents an object which can be ordered along a dimension $\delta$ and $d$ is a function from $\boldsymbol{a}$ to a unique point on the scale $S_{\delta}$ :

$$
\begin{aligned}
& \text { a. } \operatorname{POS} \delta(a)=\left\{p \in S_{\delta} \mid p \leq d(a)\right\} \\
& \text { b. } \operatorname{NEG\delta }(a)=\left\{p \in S_{\delta} \mid d(a) \leq p\right\}
\end{aligned}
$$

The negative extent of an object on a scale $N E G \delta(a)$ and the positive one $\operatorname{POS} \delta(a)$, which are join complementary intervals on a scale, are illustrated in (53).

(53) $\mathrm{S}_{\delta} 0$ $\operatorname{POS} \delta(\mathrm{a})$ $\operatorname{NEG\delta }(\mathrm{a})$

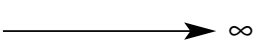

(Kennedy 1997: 201)

The distinction between positive and negative extents allows Kennedy to explain that polar adjectives, such as inteligente ('intelligent') and tonto ('silly'), denote complementary perspectives regarding the projection of an adjective on a scale: while the positive adjective (inteligente 'intelligent') conveys information about the intelligence an individual has, the negative adjective (tonto 'silly') conveys information about the intelligence an individual does not have. Positive adjectives are functions from objects to positive extents; negative adjectives are functions from objects to negative extents.

Based on Kennedy's work, Castroviejo (2006) argues that poco ('little') reverses the direction of the extent on the scale in which the adjective modified by it is projected. Thus, if poco modifies a positive adjective, the extent in which is projected grows to 0 , and not to $\infty$; when the adjective modified by poco is negative, the relevant extent does not grow to 0 , as usual in negative extents, but to $\infty$. Note that, according to this proposal, adjectives preceded by poco are projected on the same extent, and not on the opposite one. In other words, 'poco + Adjective' is not equivalent to the antonymous adjective of the polar opposition; someone who is little intelligent is not necessarily stupid.

The exclamatives illustrated in (49) have two properties that distinguish them from the ones in which poco do not occur: (a) the direction of the relevant extent is reversed and (b) the degree on the scale that holds the subject is lower than the one expected by the speaker. Precisely, my analysis of the sensitivity of exclamative quantifiers is based on the interaction between those properties, so that in order to check whether the hypothesis developed can account for the exclamatives in 
(49) it is necessary to study what happens in these cases. Let us look at the examples in (54) and (55):

(54) a. ¿Qué inteligente es María!

'How intelligent Mary is!'

b. 0

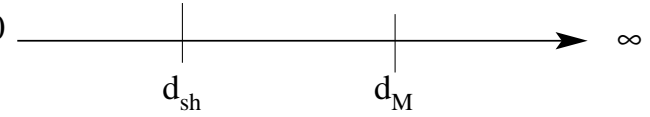

(55) a. ¡Qué poco inteligente es María!

'How little intelligent Mary is!'

b. 0

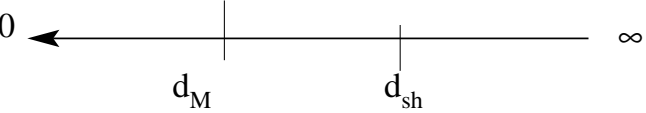

In (54a), the relevant extent on the scale, which is the positive extent, grows to $\infty$, that is, to the highest degree on the scale (cf. 54b), and, as a consequence, given a degree $x$ and a degree $y$, such that $x$ is higher on the scale than $y$, the sentence Mary is $x$ entails Mary is $y$. Since the degree on the scale in which Mary is intelligent $\left(d_{M}\right)$ is higher than the one expected by the speaker $\left(d_{s h}\right)$ (cf. 54b), the former implies the latter. The same reasoning can be extended to the exclamative sentence in (55a), the only difference being that the direction of the extent and the order between the degree that holds the subject and the degree expected by the speaker are the opposite ones. Poco reverses the direction of the positive extent in which the adjective inteligente is projected, so that the extent in (55), unlike what happens in (54), grows to 0 (cf. 55b). This means that the order between the degrees on the scale is also reversed; if a degree $x$ is higher than a degree $y$ in (54), $y$ is higher than $x$ in (55). Therefore, although the degree in which the subject of predication is placed in (55) is apparently lower than the one expected by the speaker, the former is higher than the latter; in other words, the degree of intelligence of María $\left(d_{M}\right)$ entails the one expected by the speaker, in the same way as in (54).

Since the degree that holds the subject of predication entails the one expected by the speaker in (54a) and (55a), both constructions fit into Zanuttini and Portner's (2003) description of exclamative sentences: the exclamative quantifier widens a domain of quantification leading to a stronger statement. This allows us to extend the analysis developed in order to explain the impossibility of negating an exclamative sentence such as *iQué inteligente no es María! ('How intelligent Mary is not!') to exclamatives which contain poco (;Qué poco inteliegente no es María! 'How little intelligent Mary is not!'): negation reverses scalar implicatures and, as a consequence, the extension induced by the exclamative quantifier does not lead to a stronger statement, but to a weaker one.

Summarizing, the sensitivity of exclamative wh-phrases to downward-entailing environments is due to the fact that the domain expansion caused by them does not strength the statement. This results in a violation of the strengthening principle 
which must be satisfied in domain-widening functions (cf. Kadmon and Landman 1993, Chierchia, 2004). ${ }^{24}$

\subsection{Summary}

The restrictions on the scope relations established between exclamative wh-phrases and negation are due to two factors: (a) the wh's denotation domain, and (b) the sensitivity of exclamative wh-phrases, which are positive polarity items. The former is a clue to understanding the restrictions on the scope relation in which the wh-phrase takes scope over negation. This configuration is possible when the whphrase ranges over an unordered set, as in quantitative exclamatives, but not when it ranges over an ordered set, as in qualitative exclamatives (cf. Szabolcsi and Zwarts 1997). The latter is crucial to understand why the wh-phrase cannot be within the scope of negation. Exclamative operators extend a domain of quantification within strengthening the statement. Thus, they do not satisfy the strengthening condition which must be present in the widening of a domain of quantification (cf. Kadmon and Landman 1993, Chierchia 2004), causing the derivation to converge under that configuration. This analysis allows us to explain why quantitative exclamatives can be negated, whereas qualitative ones cannot. Since quantitative exclamatives can range over an ordered domain, the wh-phrase is able to have wide scope, yielding the grammaticality of the sentence. In contrast, qualitative exclamatives range over ordered sets, and, therefore, the wh-phrase cannot outscope negation. The other configuration is not possible either, so that the wh-phrase is a positive polarity item. As a consequence, this type of exclamatives does not allow the presence of negation.

24. More empirical evidence for my hypothesis comes from a certain type of quantifiers which extends a domain of quantification without being exclamatives, such as sorprendentemente ('surprisingly'), increíblemente ('unbelievably'), etc. If, as Morzycki (2004) argues, these operators widen a domain of quantification towards the top of a scale, my analysis predicts that they should be sensitive to downward- entailing contexts. This prediction is borne out, as is shown by the ungrammaticality of *Sus alumnos no son sorprendentemente tontos ('His students are not surprisingly stupid') and ??/*Los asesinos en serie raramente están increíblemente locos ('Killers are rarely unbelievably crazy').

As a reviewer points out, degree quantifiers that denote excess do not behave as PPIs, since they can appear in negative sentences (Sus alumnos no son demasiado tontos 'His students are not too stupid'). Although I leave this topic for future work, I would like to suggest that the different behavior of this type of quantifiers and elatives (surprisingly, unbelievably) is due to the fact that the semantics of these types of modifiers is not the same. While demasiado ('too much') expresses that an implicit norm has been exceeded; surprisingly, like exclamative quantifiers, denotes that the expectations of the speaker have been exceeded. See Bosque (1996) for an analysis of degree quantifiers that denote excess. 


\section{Conclusions}

This paper has explored the restrictions on the presence of negation in exclamative sentences. I have provided a description of the interaction between wh-phrases and negation. The data provided have shown that negation is allowed in exclamative sentences when it has narrow scope with respect to the exclamative wh-phrase. This scope relation is established in quantitative exclamatives, but not in qualitative ones, and, therefore, only the first type can be negated. In order to explain this asymmetry, I have assumed Szabolcsi and Zwarts's approach to negative islands, in which wh-phrases are able to take wide scope if their domain is formed by an unordered set of individuals. I have proposed that the inverse scope relation, that is, the one where the wh-phrase is within the scope of negation, cannot be established either in quantitative exclamatives or in qualitative ones because they are positive polarity items. I have shown that they are sensitive to downwardentailing contexts and have argued that their sensitivity is due to the fact that they widen a domain of quantification without leading to a stronger statement.

\section{References}

Bosque, Ignacio (1996). “On Degree Quantification and Modal Structures”. In: Parodi, C. et al. (eds.). Aspects of Romance Linguistics. Washington: Georgetown University Press, pp. 87-106.

Bosque, Ignacio and Pascual J. Masullo (1998). "On verbal quantification in Spanish". In: Fullana, Olga; Roca, Francesc (eds.). Studies on the Syntax of Central Romance Languages. Girona: Universitat de Girona, pp. 9-63.

Castroviejo, Elena (2006). Wh-Exclamatives in Catalan. Universitat de Barcelona, doctoral dissertation.

Cinque, Guglielmo (1990). Types of A'-Dependencies, Cambridge, Mass.: The MIT Press.

Chierchia, Gennaro (2004). "Scalar Implicatures, Polarity Phenomena, and the Syntax/Pragmatics Interface". In: Adriana Belletti (ed.). Structures and Beyond. The Cartography of Syntactic Structures. Oxford: Oxford University Press, pp. 39-103.

Chierchia, Gennaro (2006). "Broaden Your Views: Implicatures of Domain Widening and the "Logicality" of Language". Linguistic Inquiry 37, pp. 535-590.

Cresti, Diana (1995). "Extraction and Reconstruction". Natural Language Semantics 3: 79-122.

De Swart, Helen (1992). "Intervention effects, monoticity and scope". In: Baker, Chris; Dowty, David (eds.). SALT III: Proceedings of the Second Conference on Semantics and Linguistic Theory 40. Columbus: The Ohio State University, pp. 387-406.

Dobrovie-Sorin, Carmen (1990). "Clitic Doubling, Wh-Movement, and Quantification in Romanian". Linguistic Inquiry 21: 351-397.

Dobrovie-Sorin, Carmen (1992). "LF representations, weak islands, and the ECP". GLOW Newsletter 27: 14-15.

Espinal, M. Teresa (1997). "Non-Negative Negation and Wh-Exclamatives". In: Forget, Danielle; Hirschbuhler, Paul; Martineau, France; Rivero, M. Luisa (eds.). Negation and Polarity: Syntax and Semantics. Amsterdam: John Benjamins, pp. 75-93. 
Espinal, M. Teresa (2000). "Expletive Negation, Negative Concord and Feature Checking". Catalan Working Papers in Linguistics 8: 47-69.

Etxepare, Ricardo (1997). The Grammatical Representation of Speech Events. University of Maryland, doctoral dissertation.

Frampton, John (1991). "Relativized Minimality, A Review". The Linguistic Review 8: 1-46.

Giannakidou, Anastasia (1998). Polarity Sensitivity as (Non)veridical Dependency. Amsterdam: John Benjamins.

González Rodríguez, Raquel (to appear, a). "Reconstruction and Scope in Exclamative Sentences”. In: Eguren, Luis; Fernández, Olga (eds.). Current Studies on Syntax and Interpretation. Coreference, Scope and Focus. Selected papers from the $16^{\text {th }}$ Colloquium on Generative Grammar. Amsterdam: John Benjamins.

González Rodríguez, Raquel (to appear, b). "Scope Economy in Positive Polarity: Extreme Degree Quantification”. In: Baauw, Sergio et al. (eds.). Linguistic Theory and Romance Languages. Selected Papers from Going Romance 2005. Amsterdam: John Benjamins.

Gutiérrez-Rexach, Javier (2001). "Spanish exclamatives and the interpretation of the left periphery" in Rooryck, Johan; de Hulst, Yves; Schroten, Jan (eds.). Selected Papers from Going Romance 99. Amsterdam: John Benjamins, pp. 167-194.

Hoeksema, Jakob (1986). "Monotonicity phenomena in natural language". Linguistic Analysis 16: 19-40.

Israel, Mira (1996). "Polarity sensitivity as lexical semantics". Linguistics and Philosophy 19: 619-666.

Kadmon, Nirit; Landman, Fred (1993). “Any”. Linguistics and Philosophy 16: 353-422. Kennedy, Christopher (1997). Projecting the Adjective: The Syntax and Semantics of Gradability and Comparison. University of California, Santa Cruz, doctoral dissertation.

Kennedy, Christopher (2001a). "On the monotonicity of polar adjectives”. In: Hoeksema, Jakob et al. (eds.). Perspectives on Negation and Polarity Items. Amsterdam: John Benjamins, pp. 201-221.

Kennedy, Christopher (2001b). "Polar opposition and the ontology of degrees". Linguistics and Philosophy 24: 33-70.

Kiss, Katalin É. (1992). "Wh-movement and specificity". Natural Language and Linguistic Theory 11: 85-120.

Krifka, Manfred (1995). "The Semantics and Pragmatics of Polarity Items". Linguistic Analysis 25: 209-257.

Kuno, Susumo; Takami, K. (1997). "Remarks on negative islands". Linguistic Inquiry 28: 553-576.

Ladusaw, William (1980). Polarity Sensitivity as Inherent Scope Relations. New York: Garland.

Lahiri, Utpal (1998). "Focus and Negative Polarity in Hindi". Natural Language Semantics 6: 57-125.

Masullo, Pascual J. (2003). "Hidden Exclamatives in Spanish". University of Pittsburgh, unpublished manuscript.

Morón Pastor, A. (2004). La frase de grado compleja con adjetivos en español. Universidad Autónoma de Madrid, doctoral dissertation. 
Morzycki, M. (2004). "Evaluative Adverbial Modification in the Adjectival Projection". Université du Québec à Montréal, unpublished manuscript.

Plann, Susann (1984). “Cláusulas cuantificadas”. Verba 11: 101-128.

Portner, Paul; Zanuttini, Raffaella (2000). "The Force of Negation in Wh Exclamatives and Interrogatives". In: Horn, Laurence R.; Kato, Yasuhiko (eds.). Negation and Polarity. Syntactic and Semantic Perspectives. Oxford: Oxford University Press, pp. 193-231.

Rizzi, Luigi (1990). Relativized Minimality. Cambridge, Mass.: The MIT Press.

Ross, John R. (1984). "Inner Islands”. Proceedings of BLS 10, University of California, Berkeley, pp. 258-265.

Sánchez López, Cristina (1999). “La negación”. In: Bosque, Ignacio; Demonte, Violeta (eds.). Gramática descriptiva de la lengua española. Madrid: Espasa Calpe, pp. 1025-1128.

Szabolcsi, Anna (2006). "Strong vs. Weak Islands". In: Everaert, Martin; van Riemsdijk, Hans (eds.). The Blackwell Companion to Syntax. Oxford: Blackwell, pp. 479-531.

Szabolcsi, Anna; Zwarts, Frans (1997). "Weak islands and an algebraic semantics for scope taking”. In: Szabolcsi, Anna (ed.). Ways of Scope Taking. Dordrecht: Kluwer Academic Publishers, pp. 217-262.

Torrego, Esther (1988). "Operadores en las exclamativas con artículo determinado de valor cuantitativo”. Nueva Revista de Filología Hispánica 36: 109-122.

Tovena, Lucia (1998). The Fine Structure of Polarity Items. New York: Garland. van der Wouden, T. (1997). Negative Contexts. Collocation, Polarity and Multiple Negation. London: Routledge.

Villalba, Xavier (2004). "Exclamatives and negation". Report de recerca, Grup de Gramatica Teorica, Universitat Autònoma de Barcelona (http://seneca.uab.es/clt).

Von Fintel, Kai (1994). Restrictions on Quantifier Domains. University of Massachusetts, Amherst, doctoral dissertation.

Zanuttini, Raffaella; Portner, Paul (2003). "Exclamative Clauses: At the Syntax-Semantic Interface". Language 79: 39-81.

Zwarts, Frans (1998). “Three types of polarity”. In: Hamn, F.; Hinrichs, E. (eds.). Plural Quantification, Dordrecht: Kluwer, pp. 177-238. 